THE TRI-PART MAN:

Archetype, Alchemy, and Art: The Jungian Substrate of Nabokov's PALE FIRE. (Part I)

This paper is an excerpt from a larger work-in-progress, tentatively titled, 'Archetype, Alchemy and Art: The Jungian Substrate of Nabokov's Pale Fire.' My intention is not to offer an extra-literary schema of Jungian analysis or interpretation of Pale Fire, but to present credible evidence of Nabokov's intentional use of the theories of Carl Jung as a major parodic and allegoric substrate of the novel. Here I look at the relationship of the three main characters, Kinbote, Shade, and Gradus, as the three main Jungian archetypal components of the psyche: the ego, persona, and shadow.

The relationship between John Shade and Charles Kinbote, as the two main characters of Pale Fire, has been a point of scholarly contention since Vladimir Nabokov's elaborately cryptic novel was published in 1962 . The trope of the 'double' as dissociated personality is usually cited, with arguments over which character is the real and which imagined. I argue that the much contested identity of the fictional author of both Pale Fire's poem and commentary has generally suffered from two fallacies: (1) basing a solution on the common literary trope of the 'double,' and (2) attempting to solve the question from the 'thetic' text level. ${ }^{1}$ The question of the double is basically moot on the thetic text level; there remain too many logical contradictions between poem and commentary and time/space inconsistencies. It can only be resolved by a quantum leap to the higher antithetic level of thematic texture. The tri-part Jungian model is a

\footnotetext{
${ }^{1}$ Excellent synopses of the Shadean/Kinbotian arguments can be found in Brian Boyd's Nabokov's Pale Fire, Princeton: Princeton UP, 1999 (Boyd). Boyd offers a unique solution that does not involve the "double," plus he finds the solution on the "antithetic" level, but his conclusion that the ghosts of Hazel and her father John Shade are responsible for the poem and commentary are quite different from what I present.
} 
more accurate and elegant solution to the characters' relationships and the novel's thematic cohesion.

I will be looking at the three characters as virtual equals, as archetypes of the three parts of the psyche: ego conscious, higher conscious and lower conscious. These elements form the 'Tri-part Man,' a notion common to a many metaphysical systems, but most clearly evinced in Pale Fire through psychologist Carl Jung's theories of archetypes and alchemy. Kinbote, Shade, and Gradus, clearly indicate the attributes of Jung's ego, persona and shadow archetypes as sub-personalities within the psyche of one man. That man, however, is not one of the three, but the three-in-one: the novel's absent and enigmatic cipher, Professor V. Botkin, as stand-in for Nabokov. Botkin's metaphysical quest for transcendence is a parodic allegory presented in the form of Jungian individuation.

Per Nabokov's stated method of composing in 'thetic spirals' (thetic, antithetic and synthetic) the play-out of the drama of the archetypes takes place on a separate level of fictive space parallel to the text (thetic) level. At this parallel (antithetic) level of themes, parody, paronomasia, allusions and allegory, the characters' relationships and motivations are revealed through the Jungian archetypes. Thus archetypal characters enact the drama of Jungian "individuation," the unification of the transcendent self through the confrontation and assimilation of the archetypes into consciousness. The metanarrative, as evinced by the archetypes and individuation, is the novel's triple theme of transcendence - of death (Gradus), of ego (Kinbote), and ultimately of art (Shade). 
I begin with a review of the controversy followed by Nabokov's clear authorial encodings of the tri-part man theme, then present the universality of the tri-part man concept, which includes Jung's theories of archetypes and alchemy. With this as basis, I look separately at how Gradus, Shade, and Kinbote indicate the attributes specifically of Jung's shadow, persona and ego archetypes. In conclusion, I pose another question, "In the end, does Botkin successfully transcend?" I leave that answer ambiguous and unresolved. That intriguing riddle will be further addressed in a forthcoming paper, 'Sybil: Spider at the Center of PALE FIRE's Web of Sense.'

\section{THE CONTROVERSY}

The controversy over the relationship of Pale Fire's main characters has been covered by a number of critics and vigorously debated on the Nabokovian Listserve. It has generally been conceded that the relation of poem and commentary only makes sense if written by the same person. Conversely, temporal logic does not allow for Kinbote and Shade to be in the same time/space as other 'real' characters of New Wye. The debate has been divided between the 'Shadeans' and the 'Kinbotians' as to just who that person is. Perhaps both are actually Professor V. Botkin? Critics seem to intuitively guess, but fail to find proof, that the tantalizingly near-anagrammed professor is somehow behind the Janus-masked author of both poem and commentary. Although Nabokov himself admitted, in a 1962 interview with the New York Herald Tribune, that Botkin, not Kinbote, was the commentator, he remained typically cryptic by not actually asserting positively that Kinbote was, in fact, Botkin's only avatar: 
[Pale Fire] is full of plums that I keep hoping somebody will find. For instance, the nasty commentator is not an ex-King of Zembla nor is he professor Kinbote. He is professor Botkin, or Botkine, a Russian and a madman. ${ }^{2}$

The 1962 interview remained fairly unknown until unearthed in the Nabokovian Listserve in $2006 .{ }^{3}$ Botkin has clearly undergone a psychotic break and is imagining himself to be Kinbote hallucinating himself as the King of Zembla. This sets up the scenario of multiple sub-personalities. ${ }^{4}$ Despite Nabokov's assertion of V. Botkin as commentator, the essential conundrum of the relation of poem to commentary (logically and artistically), and the corresponding relationship of Shade to Kinbote has remained unresolved. The character Jacob Gradus has sometimes been brought in as a third imagined or dissociated personality, however it remains unclear as to who is doing the dissociating, and logical problems remain between poem and commentary, and between 'real' New Wye and imaginary Zemblan narratives.

The controversy, if not fully resolved, abated with the publication of Brian Boyd's impressive 1999 work, Nabokov's PALE FIRE 5 . Boyd reverses his previous Shadean position to suggest that the characters are the separate individuals they appear to be on the text level (at least of New Wye reality). I feel that Boyd's proposition of Hazel and John Shade's blithe spirits joining forces to enrich Kinbote's fantasies is a misreading of the text and style; the theory of generous spirits seems unlikely. Shade, we shall see, is not always the kindly soul he seems and Nabokov is an ironic author ${ }^{6}$, with at best,

\footnotetext{
${ }^{2}$ Interview with Maurice Dolbier. New York Herald Tribune Books 17 June 1962.

${ }^{3} \mathrm{http}: / /$ thenabokovian.org/node/19096

4 A subject, by the way, of central concern to Carl Jung which led to his theory of archetypes.

${ }^{5}$ Boyd, Brian. Nabokov's Pale Fire: The Magic of Artistic Discovery, Princeton: Princeton University Press, 1999.

${ }^{6}$ Pale Fire evinces all the qualities of an ironic novel as outlined by the eminent literary critic Northrop Frye, whose 'Archetypal Literary Criticism' was widely esteemed in the 1950's, and whose theories I suspect are actually parodied in Pale Fire as part of the theme of Kinbote's critical commentary. Frye was influenced by the work of Carl Jung.
} 
ambiguous endings. Nabokov leaves ample space between the lines to indicate that Hazel's relationship with both parents was alienating and rejecting, and Shade was indifferently aware of his neighbor Kinbote, and Hazel never even met him. Would Shade actually aid and abet the theft and misappropriation of his poem? I do not intend a point-by-point polemic; the main issue I find is that Boyd's theory offers only a very small role for Gradus, not to mention for Botkin.

The dissociated double trope indicates a psychic break, but does not suggest the possibility of psychic wholeness as does the Jungian tri-part man, and thus does not connect to the novel's central theme of the quest for transcendence. Jung felt that the eruption of unconscious material had the potential to lead to either psychosis, or the first step on the path to psychic wholeness, which he termed individuation. In 2009 Roth and DeRewel presented a theory of psychological dissociation for the three characters. Their contention is similar to my Jungian theory. However, Roth and DeRewel are 'Shadeans,' and suggest that Kinbote and Gradus are sub-personalities that appeared after Shade's heart attack. They support their contention with the theories of dissociated personalities of Sigmund Freud and Frederick Meyers. Unfortunately they do not mention Jung, who was influenced by both men. Freud and Meyers each had theories of the tri-part man, which I include, on my chart, further on. Jung's theories of archetypes are more clearly evoked in Pale Fire. Again, not to make this polemical, the main difference is that Roth and DeRewel's theory is still on the level of plot, where matters of logic remain unresolved, particularly explicating the roles of Gradus and Botkin.

Gradus' cartoonish cardboard character is clearly a figment of Kinbote's deranged mind, so it seems problematic to give him equal billing to Shade and Kinbote, but 'Jack 
Grey,' the escaped psychopath, is even less of a character - a figure only necessary to explain the final irony of the plot - then, as Kinbote says, 'exit Jack Grey' (C, 228). Yet, as I discuss later, the 'triple' theme is found throughout the novel, and Gradus/Grey plays a crucial role.

The character of Botkin has been nearly as questioned as the Shade/Kinbote controversy. Boyd and Roth and DeRewel, like most critics, associate Professor Botkin with Kinbote. However, the Jungian paradigm of archetypes resolves both Gradus' and Botkin's roles when we see Gradus, Kinbote and Shade as shadow, ego and persona, the three main aspects of the universal tri-part man. The man in this case is Professor V. Botkin.

\section{THETIC LEVELS AND ALLEGORY:}

To support his thesis Brian Boyd cites Nabokov's stated method of composing in 'thetic spirals' (thetic, antithetic and synthetic) ${ }^{7}$. Boyd sees the first two arcs as occurring in the text - as Shade's positive achievement of his quest, then turning to the negative irony of his death. These are actually two opposing half-turns of a full spiral. His third arc is the hors texte afterlife return, or resurrection of his spirit. This third arc is basically a continuation of the plot, deduced from hints in the text. I see the thetic spiral differently. Each point on a spiral parallels and recapitulates the level below, but at a higher, expanded level. I argue that the thetic spirals are separate parallel fictive planes. The thetic is the text plot level. The antithetic is the level is a full turn of the spiral. It is the

\footnotetext{
${ }^{7}$ Nabokov, V., Strong Opinions, New York: Vintage International, Division of Random House, Inc., 1990. (SO)
} 
parallel level of textural design: allusions, intertextuality, paranomasia, motifs, tropes, metaphor and allegory. A solution is arrived at via the antithetic level that in turn informs the plot on the thetic level below and concomitantly leads to a higher synthetic level of thematic apprehension, or as Nabokov put it, "poignant artistic delight."

The 'double' trope does not adequately amplify or unify a central theme. The Jungian tri-part man is in accord with a central theme that I am calling 'transcendence.' The character and textual relationships can be resolved hors texte antithetic level, where we find 'not text, but texture'(P, 59). Solutions to many unresolved questions of character relationships, plot resolutions and thematic coherence of the novel can be discovered through investigating the hidden, yet pervasive, presence of Jung's theories woven into the 'underside of the weave'(F, 12) - Nabokov's intimation of the antithetic level. Here archetypal characters enact the drama of Jungian individuation, an allegory of unification of the transcendent self through the confrontation and assimilation of the unconscious archetypes into consciousness. The allegoric antithetic level then reveals and informs the thetic plot level for an elegant synthetic solution.

\section{AUTHORIAL ENCODINGS of the TRI-PART THEME:}

Before delving further into my argument how Jung's theories of archetypes and alchemy support the theory of an allegoric tri-part man as solution to Pale Fire's relationships and themes, first we will investigate further why the theme of the double is inadequate to explain the novel's main characters. The tri-part man theme is encoded in

\footnotetext{
${ }^{8}$ Nabokov, V. Speak Memory, p.287
} 
the major markers of novel: the title, the poem's first line, the parody of the poem's

Popeian heroic couplet, Kinbote's concluding rant, and in the index.

The Title:

The triple motif is foreshadowed in the novel's title, 'Pale Fire,' and is taken from

\section{Shakespeare's Timon of Athens:}

The sun's a thief, and with his great attraction Robs the vast sea; the moon's an arrant thief, And her pale fire she snatches from the sun; The sea 's a thief, whose liquid surge resolves The moon into salt tears; the earth's a thief, That feeds and breeds by a composture stolen From general excrement: each thing's a thief. ${ }^{9}$

We see this 'stolen' quality especially in the moon's reflection of the sun (Kinbote's appropriation of Shade's art), and in the words 'pale fire' the many references in the novel to light, reflections, mirrors, nacre, luminescence, opalescence, sparks, etc.

There are multiple levels of this theme of theft, or borrowing, including Nabokov's 'cryptomnesic' ${ }^{10}$ parodies of the works of others, including as I contend, Carl Jung. Jung was the $20^{\text {th }}$ Century's foremost exponent of alchemy as a proto-psychological system.

He wrote the following about the symbols of sun and moon:

There are mythological theories that explain everything as coming from the sun and lunar theories that do the same for the moon. This is due to the simple fact that there are countless myths about the moon, among them a whole host in which the moon is the wife of the sun...The moon is the changing experience of the night, and thus coincides with the primitive's sexual experience of woman, who for him is also the experience of the night. But the moon can equally well be the injured brother of the sun, for at night affect-laden and evil thoughts of power and revenge may disturb sleep. The moon, too, is a disturber of sleep, and is also the abode of departed souls, for at

\footnotetext{
${ }^{9} \mathrm{Wm}$. Shakespeare, Timon of Athens, Act IV, iii

${ }^{10}$ Jung authored a paper for the SPR on the subject of 'Cryptomnesia,' unconscious literary appropriation (which VN uses consciously in PF). Jung, $C W, 1, \mathrm{p} .95 \mathrm{ff}$
} 
night the dead return in dreams and the phantoms of the past terrify the sleepless. Thus the moon also signifies madness ('lunacy). ${ }^{11}$

The above quote is rather uncannily reflected in Pale Fire: from the allusions of the relationship of sun and moon in the title, to the anima ${ }^{12}$ (experience of woman) associations of the feminine moon, to the feminine moon sometimes appearing as a brother (i.e. Kinbote, and possibly the reason he is portrayed as homosexual), to the disturbed sleep (Shade, Kinbote, Gradus, and Nabokov), to the departed souls and phantoms (Hazel), and to lunacy (Kinbote).

Note that sun, moon, sea, and earth have a circular relationship. They are, then in a sense, united and interdependent. Although there are four 'characters' here, they may be reduced to three, as both the sea and the land are part of the 'earth.' This imagery is taken from alchemy. The alchemic process usually combined three elements (sulphur, salt, and mercury or lead), which were considered Sun, Moon, and Earth. Metaphorically, psychologically, and alchemically, this is a united triad of 'spirit/soul/body' - the tri-part man (see chart).

The alchemists claimed that their opus proceeded from the 'one' and lead back to the 'one,' like a dragon biting its own tail (uroboros), and therefore called the process rota (the wheel). Thus, the image suggested by the title foreshadows the form of John Shade's poem, with the last line suggesting a return to the beginning (it also reflects Shade's poem, 'Night Rote'). Jung often discussed the uroboros symbol, which is a 'mandala' and symbolizes unity consciousness and the process of continual death and resurrection, an apt symbol for Pale Fire's structure and theme.

\footnotetext{
${ }^{11}$ Jung, $C W, 8$, p. 154.

${ }^{12}$ See my papers Mary Ross, 'Vanessa-atalanta: Butterfly of Doom', in The Nabokovian: Notes, Spring 2018 (MR1) and 'Sybil: Black Widow Spider at the Center of Pale Fire's Web of Sense,' (MR3) unpublished.
} 
Shakespeare wrote during the efflorescence of $17^{\text {th }}$-century alchemy. One of the characters in Timon, in fact, is an alchemist. Another character is a poet. Timon himself is a solipsistic buffoon. These three characters bear a resemblance the three archetypal characters in Pale Fire: Kinbote, like Timon, as inflated ego; John Shade the poet as senex (Wise Old Man), or idealized persona ${ }^{13}$, and Gradus as shadow resembles alchemy's dark, degraded element, Mercurius.

The Poem's First Two Lines:

The haunting but perplexing first couplet of John Shade's poem, 'I was the shadow of the waxwing slain/ In the false azure of the windowpane,' subtly iterates the theme of the tri-part man. I interpret young John Shade's experience as looking out the window from the inside and noticing only the shadow of the unseen waxwing as it traverses across the landscape. Hypnotically entranced, as this sensitive lad was subject, he identifies with the oncoming shadow, until both bird and shadow collide on the windowpane, the shock causing the enrapt boy to feel himself annihilated. Bringing the opposites of the conscious and unconscious minds together to achieve psychic wholeness (individuation) is the basis of Jungian psychology. For young John Shade witnessing the bird and its shadow, this confrontation takes place on the mirrored glass, the plane where opposites meet.

Three entities are mentioned: 'I', 'shadow' and 'waxwing.' Each can be seen as an archetype. 'I' is the ego. The shadow is the Jungian term for the archetype of the lower repressed aspect. The higher aspect is the Dedalian spirit of transcendence of the

\footnotetext{
${ }^{13}$ Shade's curious ambiguous archetype - both 'senex' and 'persona' - is dealt with further on.
} 
waxwing (senex, a.k.a Wise Old Man). However, the waxwing is flying in a 'false' azure. It is more like Icarus attempting a feat it is incapable of. The attempt to be something one is not is what Jung termed the persona, the false self. In these first two lines, the ego states that it is synonymic with the shadow (I was the shadow); this is young John Shade realizing (identifying with) his shadow. However, the shadow belongs to the persona (it is of the waxwing). The shadow and the persona form a polarity of opposites, the high and the low of the personality, the ego.

In the Jungian paradigm, the ego, having denied its lower shadow aspect wants to soar like its higher aspect, but it is aspiring to a 'false azure,' i.e. its own intoxicated ${ }^{14}$ glory. The ego identifies with its idealized higher nature and so creates a false nature, the persona (Jungian 'mask'), by only acknowledging this ideal aspect and repressing the shadow. Psychologically, to truly transcend (individuate), the ego has to confront and acknowledge its dark hidden shadow. This requires dis-identifying solely with the false idealized self (persona), as well. Actually, when the ego confronts and acknowledges its dark shadow side, the vaunted false persona cannot be sustained, thus is automatically 'slain,' along with its shadow. They become subsumed consciously into the true self, as Jung termed the totality of the ego and the lower and higher archetypes. This explains young Shade's transcendent unity experience. Presumably coming-to after his mystical swoon, the boy sees the mark of the impact, the bit of 'ashen fluff,' which appears from

\footnotetext{
${ }^{14}$ Waxwings become intoxicated on fermented berries and as a result, are known to fly into windowpanes. We might note that the adult John Shade has a drinking problem.
} 
the inside to be floating away in the outside sky, merging both sides of the glass. This remnant from the collision indicates the transformed, transcendent self. The residue of 'ashen fluff' may be a metaphor of what is left of the ego in the middle: the result and residue of alchemy's combining of opposites, the ashy 'stone.' The ashen fluff smudged on the windowpane appears to be floating in the outer sky, symbolic of transcendence.

Jung called the ability to unite the opposites the 'transcendent function.' The theme of transcendence - of ego, of life, and above all the transcendence of Art - I suggest, again, is the overarching and unifying theme of Pale Fire.

Popeian Parody of the Poem:

John Shade is a scholar and fan of Alexander Pope. His poem is written in a neoPopeian style of heroic couplets. Line 419, 'See the blind beggar dance, the cripple sing,' directly references Pope's An Essay on Man, a witty and ironic look at the folly of pride (ego) in every man. The essay is, in fact, an astute psychological commentary on how pride is evinced in the three basic types we are discussing (ego, shadow, and persona). Pope's poem continues:

See the blind beggar dance, the cripple sing, The sot a hero, lunatic a king;

The blind beggar and the cripple are both disfigured physically, so we might easily combine them as representing the lower consciousness aspect (shadow). A classic hero is usually an extraordinary man on a transformational quest, but this 'hero' (persona) is a drunk. A king represents the ruling consciousness of thought (ego), but this 
one is insane. These three types can be seen respectively in Gradus, Shade, and Kinbote. Not quoted in Pale Fire, but perhaps implied, Pope mentions two other types, the chemist and the poet. They differ from the other three in that they are not corrupt:

The starving chemist in his golden views

Supremely blest, the poet in his muse.

These two figures relate to transcendent values - mysticism and poetry - and are in a sense outside and apart from the psychology of pride. Interestingly, the alchemist and poet are the same as the characters in Timon. Here they represent, I maintain, the overarching theme in Pale Fire of transcendence. John Shade is a poet; he gave a book of poems the Popeian title 'Supremely Blest.' He has access to transcendence despite his drinking and whatever other personality defects he might have (Shade, as we shall see, is part light, part dark). The chemist (i.e. alchemist) ${ }^{15}$ seeks the secret of immortality and as a magician combines and transmutes elements into spiritual 'gold;' this is Mercurius redeemed. Jung saw the alchemic process of transmutation as the alchemist's psychological purification leading to spiritual transcendence. The alchemist projected his psyche into the process of the base Mercurius transmuted to the redeemed 'stone.'

\section{Kinbote's Final Rant:}

At the novel's denouement, as his character disintegrates, Kinbote's final rant makes clear that there are 'three principals' in his imagined burlesqued melodrama of

\footnotetext{
${ }^{15}$ I earlier equated the alchemist in Timon with Gradus as the degraded element, Mercurius. In alchemy, the 'unredeemed' mercury is subjected to spiritual transformation, into which the alchemist projects his psyche; thus mercury has both an unredeemed and ultimately exalted character, the perfected magusalchemist. This transformation is another indication of the characters being aspects of one self.
} 
Pale Fire. With his idealized poet, (persona), and his dreaded foe (shadow) both dead, an apparent authorial presence comes forward and announces:

I may pander to the simple tastes of theatrical critics and cook up a stage play, an old fashioned melodrama with three principals: a lunatic who intends to kill an imaginary king, another lunatic who imagines himself to be that king, and a distinguished old poet who stumbles by chance into the line of fire, and perishes in the clash between the two figments $(\mathrm{C}, 229)$. (My emphasis)

The Index:

The first page of the Index also makes clear that Gradus, Kinbote and Shade are each 'main characters': 'The capital letters, G. K, S (which see) stand for the three main characters in this work.' (I, 231) Referring to them as 'characters' is a clear indication that, like archetypes, the three are all equally unreal.

Thus, from first to last in the structure of the novel, from the title to the first lines of the poem, to the last words of the commentary, to the index, a symbiotic relationship is hinted at: Gradus/Kinbote/Shade, the tri-partite man.

\section{UNIVERSALITY of the TRI-PART MAN:}

The notion of the tri-part man did not originate with Jung, or even with Freud's Id, Ego, and Superego. The tri-part man is a concept and has been described with slightly different terminology and nuances through various ages and cultures. The esoteric meaning behind the three-part man is not the 'three,' but the 'One,' what Carl Jung termed the 'self.' Some terminology has been confused or conflated, such as spirit/soul, 
spirit/mind, mind/ego, soul/ego, soul/unconscious, body/unconscious, etc., but basically they fall into the below categories:

The Tri-Part Man

\begin{tabular}{|l|l|l|l|}
\hline & Gradus & Kinbote & Shade \\
\hline Archetype (Jung) & Shadow & Ego & Senex or Persona \\
\hline Alchemy (Jung) & $\begin{array}{l}\text { Earth (Body)(Lead } \\
\text { or Mercury) } \\
\text { (Macrocosmic) }\end{array}$ & $\begin{array}{l}\text { Luna (Soul) (Silver) } \\
\text { (Microcosmic) }\end{array}$ & $\begin{array}{l}\text { Sol (Spirit)(Gold) } \\
\text { (Divine) }\end{array}$ \\
\hline Function (Jung) & Instinct & Emotion & Intuition \\
\hline Faculty (Jung) & Sensation & Feeling & Thinking \\
\hline Freud & Id & Ego & Superego \\
\hline SPR (Myers) & Subliminal & Liminal & Supraliminal \\
\hline $\begin{array}{l}\text { Plato, Neo- } \\
\text { Platonism }\end{array}$ & Soma, Physis & Psyche & Nous \\
\hline Gnostic & Hylic & Psychic & Pneumatic \\
\hline Christianity & Devil/Satan & Man & Christ \\
\hline Buddhism & Emanation Body & Beatific Body & Truth Body \\
\hline Hinduism (Gunas) & Material (Tamas) & Astral (Rajas) & Spiritual (Sattva) \\
\hline Judaism & Basar & Nephesh & Ruach \\
\hline Consciousness 1 & Lower & Ego & Higher \\
\hline Consciousness 2 & Unconscious & Conscious & Super-conscious \\
\hline Consciousness 3 & Dark & Confused & Light \\
\hline Person & Body & Soul & Spirit \\
\hline Body & Belly & Heart & Head \\
\hline State & Repressed & Defended & Free \\
\hline Polarity & Negative & Neutral & Positive \\
\hline
\end{tabular}

I will not be going into all these trichotomies; they are basically to show the universality of the tri-partite notion. However, note that the first four relate directly to Jung. Jung had theories of 'functions"' and 'faculties' anterior and analog to the archetypes, based in the body centers of belly, heart, and head. Importantly, Jung's theories also include the view of alchemy. Jung was also greatly influenced by 
Gnosticism and Neo-Platonism, ${ }^{16}$ both antecedents to alchemy. Note that Frederick Myers, founder of the Society for Psychical Research is included because the SPR is the template for John Shade's IPH. Myers' theories of the unconscious were similar to Jung's, and Jung was also a member of the $\mathrm{SPR}^{17}$. The remaining systems demonstrate a long world history of the tri-part man notion in religion and psychology. It might even be argued that Nabokov's tri-part man idea sprang directly from this source in the collective unconscious. Jung theorized that an inherited, universally shared 'collective unconscious' contained templates he termed 'archetypes.' This could be demonstrated by the ubiquitous myths, themes, dreams and imagery throughout human history. However, I argue for Nabokov's intentional use of Jung's theory of archetypes and alchemy as template for Pale Fire's characters and transcendent themes.

Jung's tri-part man at least is most apt for Pale Fire, employing as it does the word 'shadow' for the lower self, Gradus the Shadow. Kinbote can be easily seen as the ego writ large. Kinbote often describes his sense of 'pride.' The higher self, the senex, is appropriate for the higher aspects of elderly poet Shade. I have placed the persona in the higher category as well since the false self identifies with the ideal. Persona means 'mask,' a word used to describe Shade. We will look at these archetypes in more detail, but first a look at how ancient alchemy's notion of the tri-part man influenced Jung's archetypes and how allusions to alchemy are pervasive in Pale Fire.

\footnotetext{
${ }^{16}$ Both Jung and Nabokov in their metaphysics have often been described as 'Gnostic.'

${ }^{17}$ Roth \& DeRewal mention Meyers as source for their tri-part dissociation theory. They do not mention Jung. Jung presented papers to the SPR on the subject of dissociation. Roth and De Rewal maintain that Shade is the primary personality who, after a stroke hallucinates sub-personalities Kinbote and Gradus. My conclusions differ in that I maintain two levels of fictive space, the thetic plot level where the characters are all separate individuals, although allegoric of Jungian archetypes on the antithetic plane.
} 


\section{ALCHEMY and the TRI-PART MAN:}

References to alchemy are found throughout Pale Fire and are too numerous to mention here, but too important to ignore. An excellent paper on the subject is Lyndy Abraham's Nabokov's Alchemical Pale Fire ${ }^{18}$. Curiously, Abraham does not touch on alchemy's central tri-part theme, which is my focus in this paper. Neither does she mention the essential alchemic notion of the coniunctio - the 'chymical marriage' or combining of opposites - that is so prevalent in mirror and reflection tropes in Pale Fire. She quotes Jung several times but does not mention his seminal position in bringing the ancient art of alchemy out of arcane obscurity, realizing that it was a proto-psychological system with a goal towards spiritual completion (Jungian individuation). Jung found that his theories of uniting the conscious and unconscious through confronting and assimilating the archetypes was essentially what the alchemists were attempting to achieve-the aurum non vulgi, 'uncommon gold.' For Jung this spiritual gold equated with the archetype of the self, the integration of the whole person inclusive of the three levels of the psyche: the unconscious, ego conscious and higher conscious. The tri-unity of alchemy is the perfect metaphor for the reflections on immortality, spiritual quest, and literary transmutation and that form Pale Fire's major theme of transcendence.

The tri-part man was an essential concept of alchemy. Ancient Greek alchemy attributes the Emerald Tablet, a seminal alchemical text, to the legendary/mythic Hermes Trismegistus, who's very name (thrice-great) indicates his tri-part nature. The Emerald Tablet consisted of 14 metaphysical aphorisms; Aphorism number 13 states:

\footnotetext{
${ }^{18}$ Abraham, Lyndy. Nabokov's Alchemical Pale Fire, DQR, 20(2), pp.102-119.
} 
I am called Hermes Trismegist, having the three parts of the philosophy of the whole world. ${ }^{19}$

What are the three parts? The alchemic process was based on three elements that were combined, dissolved, recombined, reduced and purified into one thing (the 'stone'). The elements were usually mercury (sometimes lead), salt, and sulphur, which were considered 'Earth, Luna, Sol.' Mercury was the reagent that united the opposing elements of female and male (Luna and Sol) in the 'sacred marriage' (coniunctio) resulting in the birth of the filius macrocosmi, the so-called 'philosopher's stone,' (called also many other names such as 'philosophic gold,' aurum non vulgi, 'quintessence,' ‘elixir,' filius philosophorum, homo altus, and quite a few others, including -importantly -'treasure ${ }^{20}$ ). Jung explains the basic alchemic procedure:

[The] chief figure was Hermes or Mercurious, in his dual significance as quicksilver and the world soul, with his companion figures Sol (=gold) and Luna (=silver) ${ }^{21}$. The alchemical operation consisted essentially in separating the prima material, the so-called chaos, into the active principle, the soul, and the passive principle, the body, which were then reunited in personified form in the coniunctio or 'chymical marriage.' In other words, the coniuncito was allegorized as the hierosgamos, the ritual cohabitation of Sol and Luna. From this union sprang the filius sapientiae or filius philsophorum, the transformed Mercurius, who was thought of as hermaphroditic in token of his rounded perfection. ${ }^{22}$

According to Jung, although the stone was worthless to the common man, to the alchemists it was a treasure - philosophic gold - because they projected their psychology into the process after much study and contemplation and beheld in its completion the essence of the One (self).

The attributes of the stone - incorruptibility, permanence, divinity, triunity, etc. - are so insistently emphasized that one cannot help taking it as the deus absconditus in matter. ${ }^{23}$

\footnotetext{
${ }^{19}$ Jung, $C W 18$, p. 185.

${ }^{20}$ Hint to Kobaltanna

${ }^{21}$ Sometimes actual gold and silver were employed, but like the Sun and the Moon were also just metaphorical. The usual substances were mercury, salt (moon) and sulphur (sun)

${ }^{22}$ Jung, $C W 13,122$.

${ }^{23}$ Ibid. (my emphasis)
} 
Michael Maier, the $16^{\text {th }}$-century alchemist and author of the alchemical text Atalanta Fugiens (a text that will prove crucial to Pale Fire ${ }^{24}$ ) gives further information on the tri-part man. The unique structure of his book, Atalanta Fugiens, is referenced covertly in Pale Fire. It is an alchemical treatise of 50 discourses presented as musical fugues for three voices. It combined the three arts of poetry, music and engraved illustrations ('emblemata'). The musical fugue structure was in counterpoint. There is attendant commentary ('Epigramma') on each illustrated poem/song. Like other alchemists of the time, Meiers occasionally uses 'argot,' a secret language employed to mystify through anagrams and wordplay. Typical of Nabokov, anagrams and wordplay are rife in the Pale Fire, as are obscure allusions and occult references. Kinbote, while speaking of Shade, hints at Maier's work:

I am witnessing a unique physiological phenomenon: John Shade perceiving and transforming the world, taking it in and taking it apart, recombining its elements in the very process of storing them up so as to produce at some unspecified date an organic miracle, a fusion of image and music, a line of verse. (F, 20, my emphasis)

Not only is this a description of Shade, it exactly describes the structure of Meiers' book, and it is an apt description of Pale Fire as well. Pale Fire combines multiple literary source-elements and recombines all into a singular work of art. Pale Fire has a fugue-like structure; the three main characters, you could say, are contrapuntally 'singing the same song.' The theme of the song one might call 'individuation.' All three characters are striving to realize themselves. John Shade is on an eschatological mission to understand Being and the beyond. Kinbote is on a mission to BE someone, to be recognized as 'King,' to tell his (egoic) story, which happens to conform to the classic

\footnotetext{
${ }^{24} \mathrm{c} f$ my paper 'Vanessa Atalanta: Butterfly of Doom.' (MR1) The myth of Atalanta is the alchemical explanation for the union of opposites. The figure of Atalanta reveals the issue in Pale Fire of issues with the anima.
} 
mythical Hero's Journey ${ }^{25}$ of Jungian individuation. Even Gradus, as shadow is on a mission to come to consciousness - via revolution (i.e. psychologically, the repressed, rejected self breaking through the unconscious to become conscious).

Meier's foreword ('Epigramma Authoris') relates the Greek myth of Atalanta and Hippomenes, which is an allegory of the alchemical coniunctio, or 'chymical marriage' of opposites. One of the important (for Pale Fire) epigramma in Meier's book (No. XXXIX) explains the esoteric meaning of the riddle of the Sphinx. It is hardly surprising that Nabokov would use the world's foremost riddle for his most recondite work. The common answer to "what walks on four legs in the morning, two legs in the afternoon, and three in the evening is 'Man.' Meier writes the following remark about the Sphinx's riddle, in which he states that the esoteric solution is shown in occult geometry:

But they who interpret concerning the Ages of Man are deceived. For a Quadrangle of Four Elements are of all things first to be considered, from thence we come to the Hemisphere having two lines, a Right and a Curve, that is, to the White Luna; from thence to the Triangle which consists of Body, Soul, and Spirit, or Sol, Luna, and Mercury. ${ }^{26}$

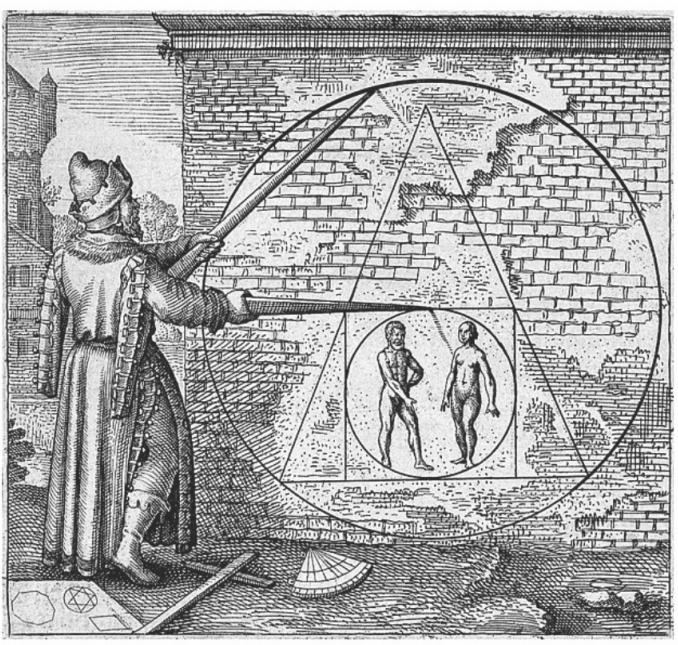

Emblem No. XXI

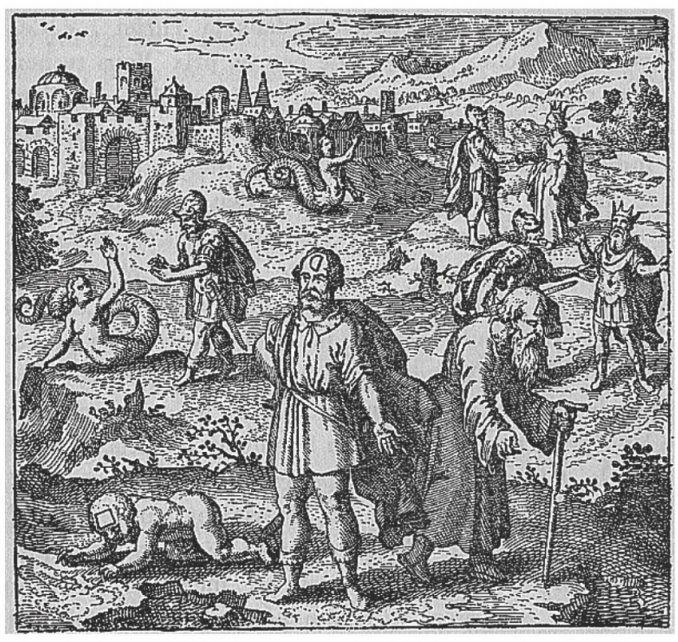

Emblem No. XXXIX

${ }^{25}$ cf my paper Kinbote's Hero's Journey (MR6) where I demonstrate Kinbote's trajectory follows Joseph Campbell's classic heroic path.

${ }^{26}$ Meier, Atalanta Fugiens, p.163. 
The geometrical image can be seen in his Emblem XXI, rather than the one accompanying Emblem XXXIX, which illustrates the Sphinx story. ${ }^{27}$ This esoteric solution is more complex than it is possible to explain here. The important thing to note is the theme of Body/Soul/Spirit, which is Mercury/Luna/Sol, which, in our text, is also Gradus/Kinbote/Shade, three aspects of man in one. It is also fitting that the 'common' answer to the Sphinx's riddle fits Pale Fire, as well: The lower instinctual nature (infant or animal) crawls on all fours. Beastly Gradus' abnormally long arms and 'chimpanzee slouch of his broad body' $(\mathrm{C}, 152)$ give him a simian appearance; a grown man (conscious ego) walks upright independently (or as an inflated ego like Kinbote, 'proudly') on two, and an old man accepts the help of a cane (higher wisdom and humility). John Shade, remember, walks with the help of a cane.

These esoteric allusions to alchemy make Pale Fire's three main characters ideal subjects for an allegorical literary treatment.

\section{ALLEGORY and the TRI-PART MAN:}

\footnotetext{
'Ask yourself if the symbol you have detected is not your own footprint. Ignore allegories, By all means place the "how" above the "what" but do not let it be confused with the "so what." Rely on the sudden erection of your small dorsal hairs. Do not drag in Freud at this point. All the rest depends on personal talent.'

(SO, p.66).
}

Allegory is almost as touchy a subject in Nabokov criticism as psychoanalysis.

Protestations and dissembling notwithstanding, I maintain that Nabokov intentionally

\footnotetext{
${ }^{27}$ Interesting to note: The sphinx is shown as a mermaid. The sphinx and the mermaid are both alchemical symbols that Jung relates to the anima. In Pale Fire, the mermaid is suggested in the alluring anima figure of Fleur and the allusion of Sybil's 'ruby ring' to Scott's poem, The Mermaid. The image is reversed in Zembla's national play, The Merman.
} 
'drags in' Jungian allegory - as parody. Pale Fire exhibits all the qualities of allegory defined in the Oxford Dictionary of Literary Terms ${ }^{28}$ :

'[...] a story or visual image with a second distinct meaning partially hidden behind its literal or visible meaning. The principal technique of allegory is personification, whereby abstract qualities are given human shape - as in public statues of Liberty or Justice. An allegory may be conceived as a metaphor that is extended into a structured system. In written narrative, allegory involves a continuous parallel between two (or more) levels of meaning in a story, so that its persons and events correspond to their equivalents in a system of ideas or a chain of events external to the tale $[\ldots]$

The "levels of meaning" and 'structured system' are particularly important to note here. If we see the Jungian archetypes as existing on a parallel level (the antithetic) to the plot (thetic) level, the relationship of the characters and the play-out of their actions on the thetic level become clear; This Jungian substrate provides a structure for the novel and the thetic plot. Although it is not the sole comprehensive constituent of antithetic level, it is where the Jungian allegory and parody finds commonality with the novel's multifarious tropes and allusions of transcendence.

Critic Northrop Frye distinguishes between 'naïve' didactic allegory and allegory that is used as creative counterpoint to a poem or plot of a novel: 'Allegory, then, is a contrapuntal technique, like canonical imitation in music.'29 Frye, whose Jungian influenced theories of 'Archetypal Literary Criticism' may even be specifically parodied in Pale Fire, also claimed that sophisticated ironic literature tended to return to the mythical and allegoric.

"Old storytelling devices," said Van “may be parodied only by very great and inhuman artists..."30

\footnotetext{
${ }^{28}$ Baldick, Chris, Oxford: Oxford University Press, Inc., 2009.

${ }^{29}$ Frye, Northrop. Anatomy of Criticism, Princeton: PUP, 1957, p.90. Frye's 'scientific' survey and categorization of the Western literary canon includes most of the literary luminaries referenced in Pale Fire. The ascendency of Archetypal Literary Criticism in the 1950's suggests its use as parody in Pale Fire: Kinbote is exactly the type of solipsistic and sloppy critic Frye warns of.

${ }^{30}$ Ada, p.246
} 
In the 'old storytelling device' of allegory, characters enacted archetypes to convey a larger theme. With Pale Fire Nabokov had the artistic confidence to brilliantly parodize, not only the genre, but at the same time current trends in psychoanalysis and literary criticism.

\section{ARCHETYPES and the TRI-PART MAN:}

We will now look more in depth at Jung's archetypes and examine the evidence within Pale Fire of their intentional use. Jung posited that the collective unconscious consisted of 'archetypes,' image-producing templates common to all humanity, although evinced with associations personal to each individual or culture. The archetypes, because they are unconscious, tend to operate as autonomous sub-personalities, or they may be unrecognized projections onto others. The goal of Jungian individuation is to bring consciousness to the unconscious archetypes by assimilating them into a unified self. The self is not the ego, but the ego is a complex that evolves out of the self-archetype through personally constellated complexes; hence the ego is itself an archetype. The difference is that the separated ego is not aware of the unconscious; the self is the totality: conscious, unconscious and higher conscious. The task of individuation is to subsume the archetypes by bringing them to consciousness, thus having access and awareness of one's complete self, while depotentiating the autonomy of the archetypes.

An effective individuation is a transcendence of the ego. Transcendence, I said, is Pale Fire's overarching synthetic theme. It is a more accurate word than 'hereafter' the translation for Vera Nabokov's 'potustoronnost', which she claimed was Nabokov's 
consuming concern. 'Transcendence' covers not only the concept of the afterlife, but also spiritual ego-transcendence, and, most importantly, the spiritual-aesthetic transcendence of art. These three notions of transcendence cover, in essence, most (or perhaps all, if really followed down) the multifarious tropes and allusions of the novel.

The relationship of Pale Fire's main characters begins to make sense when viewed as archetypes of one man's (Botkin) psyche on his journey of transcendence. Next, we will look separately at each of the three.

\section{The Shadow/Gradus:}

There are far more people who are afraid of the unconscious than one would expect. They are even afraid of their own shadow. ${ }^{31}$

Jung described the shadow as everything one denies in one's self and relegates to the unconscious or projects negatively onto others. Psychic instability occurs when the shadow contents push towards consciousness and cannot be kept hidden. Such a situation can lead either to psychosis, or, when the archetypes are faced and absorbed into consciousness, to the first step on the path to wholeness (individuation).

The shadow is a moral problem that challenges the whole ego-personality, for no one can become conscious of the shadow without considerable moral effort. To become conscious of it involves recognizing the dark aspects of the personality as present and real. This act is the essential condition for any kind of self-knowledge, and it therefore, as a rule, meets with considerable resistance. ${ }^{32}$

Jung equated the shadow with the alchemic figure of Mercurius in his untransformed (base) state. Gradus' aliases associate him with Mercurius in the first stage of alchemy, the dissolution, or blackness (nigredo). Gradus' epithets, 'Raven' and

\footnotetext{
${ }^{31}$ Jung, 9i, p.317.

32 Jung, 9i, p.292.
} 
'Ravenstone,' are synonyms for the caput corvi (raven's head) as the nigredo was sometimes referred to. It was also called the 'head of Mercurius,' who was identified as the Raven, which explains the headless statue of Mercury in the castle tunnel. For the alchemists, the nigredo was the filthy and dark, degraded aspect of the elements (like the unconscious) that needed to be purified. The nigredo was sometimes followed by a bloated, bubbling, expulsive vitriol called the 'Toad,' which would explain the eruption of Gradus' dyspeptic bowels as he nears the completion of his dark mission.

The protean figure of Mercurius has many guises in alchemy from equivalent to the Devil himself to an equal of Christ, as he becomes transformed (redeemed) in the alembic. The alembic was made of glass and it needed to be 'hermetically sealed,' so as not to allow the volatile and dangerous mercury to escape (just as psychologically the ego feels the need to constrain the shadow). They sometimes called the stone the vitrum aureaum (golden glass). The pervasive tropes of glass, mirrors, and reflections carry this alchemic and psychological theme of opposites. Zembla, the chimerical land of semblances is 'Arcady' through the looking glass. The plane of the mirror is where opposites meet, and the bringing together of opposites was the essential concept behind alchemy, which Jung saw as equivalent to his theories of bringing the unconscious to consciousness.

I have often discussed this problem with the late Prof. Paulai, who was also fascinated by what he called the mirror-reflection, causing the existence of two worlds, which are really united in the speculum, the mirror that is lying in the middle. ${ }^{33}$

Gradus' anagrammatic mirror double is Sudarg of Bokay, the talented creator of stained glass and cheval glass. Curiously, Pale Fire's index under 'Sudarg' indicates 'life

\footnotetext{
${ }^{33}$ Jung, Letters of C.G. Jung, V. 2, 469, G. Adler \& A. Jaffe, eds., R.F.C. Hull, Trans., 1976.
} 
span unknown.' Sudarg, the 'patron saint' of Zembla and creator of mirrors - that is, the reflected 'unreal' world - suggests the Gnostic demi-urge (in alchemy the filius microcosmi). He represents the 'redeemed' transmuted Mercurius, the higher creative aspect dwelling in the unconscious, while Gradus is the unredeemed volatile Mercurius, everything contrary and destructive. Mirrors were first made with mercury in the $16^{\text {th }}$ Century. Alchemists, in fact, developed the art of glass making. This is why Gradus and the Shadows are implicated in the explosion in the glass factory that precipitated the Zemblan revolution - psychologically a breaking through, or 'revolution' in consciousness. This is why the evil 'experimentalist, madman and traitor,' the Shadow, Baron Mirador Mandevil, ${ }^{34}$ whose name explains it all, created the explosion.

It is not hard to make the connection that Gradus is akin to the Jungian shadow. He is not only everything Kinbote detests, but Nabokov as well: dark, dull, degraded, mechanical, humorless, inept, unclean, nasty, brutish, and short. He represents the unconscious, and therefore is described as 'mechanical,' a quality Nabokov felt as odious in men as in noisome vehicles (which Gradus loves). Gradus is constantly on the move in airplanes, trains, and cars. Jung states that Mercurius is identical to the German Wotan and the Norse Odin. ${ }^{35}$ As emblematic of Odin/Mercurius, the god of travel and wayfarers, Gradus thus would have an affinity for trucks and vehicles. (John Shade detested loud trucks - a demonstration of their contrapuntal characters.) The louder the noise, the better for Gradus, who, like Odin, is usually accompanied by rain, wind, and thunder. Kinbote's description of Gradus 'as always streaking across the sky...' $(\mathrm{C}, 105)$ is an image of the winged messenger, Mercurius. (Mercurius was also a psychopomp associated with death

\footnotetext{
${ }^{34}$ Index, Mandevil, Baron Mirador (Besides being a man-devil, his explosive first name means "watch out!" in Spanish)

${ }^{35}$ Jung, CW12, 198
} 
and the underworld, just as Gradus will usher Shade's transition to the afterlife.) Gradus worked as a messenger for revolutionary syndicalist groups (e.g. The Shadows, implying the unruly unconscious). Gradus had studied pharmacology (i.e. alchemy). His work as a glassmaker denotes alchemy. He is also associated with another art known for unleashing the Dionysian dark side - winemaking (Vinogradus).

Jung equated the shadow with fate:

'Until you make the unconscious conscious, it will direct your life and you will call it fate. ${ }^{36}$

Gradus is akin to Humbert Humbert's shadowy personified foe and foiler of conscious desires, 'McFate.' The word 'fate' is associated with Gradus numerous times:

[...] a certain fateful fact, the departure from Zembla of the would-be regicide. Never before has the inexorable advance of fate received such a sensuous form (for other images of that transcendental tramp's approach see note to line17.) (C, 208)

'Transcendental' might seem like a strange description of Gradus, but viewed from the Jungian and alchemical perspective, the unconscious (Mercurius) contains the key to spiritual transcendence and Gradus is the instrument that will implement this.

What was Gradus doing that day? Nothing. Combinational fate rests on its laurels." (C, 178, Again, the word "combinational" suggests alchemy.)

'Two silent time zones had now merged to form the standard time of one man's

fate.' $(\mathrm{C}, 210)$ Note that it is 'one man's' fate, suggesting the combined trajectory of the

characters. Gradus' movements are continually linked with John Shade. The shadow and

the persona are a dyad of inextricably linked poles, with the ego in the middle. The

eventual meeting of the two suggests the dissolution and recombining of opposites in

alchemy or the collision of the waxwing with its shadow.

${ }^{36}$ Jung, $C W 9 i, 32$ 
'On his fateful journey he took only the battered black briefcase...' (C, 210)

Gradus has a black briefcase. Shade has a 'big black trunk, opposite the old mangle, in a niche of the little corridor leading to the so-called fruit room' $(\mathrm{C}, 83)$. There is a locked 'dusty black trunk' $(\mathrm{C}, 97)$ in the lumber-room of Kinbote's Onhava palace. Our three characters, the three aspects of the tri-part man, are synchronized by their dark 'baggage' - a vernacular word for the contents of the unconscious. The fate of the three is likewise synchronized. Their mutual fate is astrological, as well; they share the same birthday. From the allegorical standpoint of the three characters as aspects of one identity, their fates inevitably, ineluctably proceed in a fugue of triple counterpoint and converge at a mutual destination.

Gradus, Kinbote and Shade are each on a transformational path. Gradus, as emblematic of the dark rejected unconscious and the untransformed volatile Mercurius, is the element that psychologically is moving towards consciousness (individuation) and alchemical transmutation. The name 'Gradus' means 'step' in Latin and suggests the classic textbook on prosody and counterpoint, Gradus ad Parnassus. Mt. Parnassus was the Greek abode of Apollo and the Muses, so the book was designed to be gradual steps to achieving the airy heights of poetry. The two peaks of Parnassus were the realms of the antithetical gods of enlightenment and irrationality: Lycoreia (sacred to Apollo and the Muses) and Tithorea (sacred to Dionysus). We learn that Gradus comes from a winemaking family, so fittingly he is associated with the Dionysian mysteries and the abode of the occult and irrational. 'The twin peaks of Parnassus' brings to mind Jung's 
claim that the result of unleashing the shadow leads towards two possible results: either psychosis or the first step of individuation.

Jung states that in a sense, all the archetypes are shadows since they all belong to the dark unconscious. The shadow appears in many forms and guises depending on the individual's representations of personal repressions, and that there are numerous shadows within each individual's unconscious (which is why Zembla is full of Shadows). Some shadows are personal repressions and some are from deep in the collective archetypes.

With a little self-criticism one can see through the shadow - so far as its nature is personal. But when it appears as an archetype (i.e. Mercurius) one encounters the same difficulties as with the anima and animus. In other words, it is quite within the bounds of possibility for a man to recognize the relative evil of his nature, but it is a rare and shattering experience for him to gaze into the face of absolute evil. ${ }^{37}$

Gradus seems to be more of the petty, personally constellated type - Kinbote's particularly hated and rejected aspects - dull, dirty, mechanical, etc. Kinbote notes that Gradus is the type that sets mischief up but has others do the deeds. He associates this with the likes of Lenin, who he sees as a petty thug turned murderer. This mention of Lenin feels like an authorial insertion, suggesting murder as the ultimate and absolute evil.

All this is as it should be; the world needs Gradus. But Gradus should not kill kings. Vinogradus should never, never provoke God. Leningradus should not aim his peashooter at people even in dreams... $(\mathrm{C}, 120)$

When Kinbote sees Gradus coming after him and Shade, he realizes, not that he has seen before the petty criminal Jack Grey from Judge Goldsworth’s album, but, with a nightmare groan of recognition, the face of absolute archetypal Evil: 'I felt such a tremor of recognition that had I been in bed dreaming I would have awoken with a groan.' (C, 224) The unknown leader of the Shadows whose 'terrible name cannot be mentioned' (I,

${ }^{37}$ Jung, $C W 9 i i, 8$ 
Shadows, the ,238) is no doubt of the collective 'absolute evil' archetype, such as the alchemists' Mercurius in his diabolical form. For the moment, Jack Grey is the face of Death.

Gradus, as a petty shadow, is merely mechanical, stupid and blundering; as Death he is the greatest shadow whose 'terrible name cannot be mentioned, even in the Index' and who is likewise mechanical, stupid and blundering (as Nabokov would have it).

The Senex or The Persona?: Shade:

John Shade, as poet, professor and spiritual seeker evinces the qualities of the higher man. Jung called this archetype the 'Wise Old Man' or 'senex.'

The wise old man appears in dreams in the guise of a magician, doctor, priest, teacher, professor, grandfather, or any person possessing authority. ${ }^{38}$

The figure of Griff, the old mountain man who aids Kinbote, is illustrative of the fairytale type. (Jung calls the corollary figure in women's psyches the Wise Old Woman, Crone or Great Mother.) Griff and his wife are based on the myth of Philomon and Baucis who housed the disguised gods Mercury and Jupiter and were rewarded by being made eternal guardians of a temple on a mountaintop. Interestingly, Carl Jung gave his personal interior senex archetype the name 'Philomon.' The senex is often seen accompanied by a young woman, a positive anima figure who, like the senex, acts as a guide to the unconscious. This may explain in part John Shade's relation to his mystical, introspective daughter Hazel, although with a mirror twist. Hazel is repulsive rather than alluring; she evinces a rejected negative anima for Shade rather than the usual young

${ }^{38}$ Jung, CW9i, 398 
alluring positive anima (such as Griff's daughter Garh) who acts as guide to the unconscious. There is a reason for this dissonance.

Several critics have written about the dysfunctional relationship between Hazel and her parents. ${ }^{39}$ John Shade calls his daughter 'my darling,' but his over-concern with her unattractive looks and morose introversion reveals his underlying unconscious reproof. I concur with these critics and find it reason enough to doubt Boyd's theory of Hazel's beneficent transmogrification into the Vanessa atalanta butterfly. As I point out in my paper 'Vanessa Atalanta: Butterfly of Doom,' the Vanessa is a herald of doom. Allegorically, Hazel is the repressed negative anima archetype, a projection of Shade's own rejected, clumsy, unattractive, gender-insecure, preternaturally mystic childhood, which he put aside to become admirably conventional: a lauded poet, professor and community member, with a beautiful, beloved, 'perfect' professor's wife. He traded his own metaphysical certitude and allure (shame) of his mystical trances to align with conventional societal opinions and lived all his 'twisted life' in conformity and constant waffling doubt. His daughter is a constant reminder of what he has disavowed and distrusted in himself. If Hazel reincarnates as the butterfly (which, in fact, I believe she does), it is more as an omen, like a repressed archetype coming to consciousness, which, like the arising of the shadow, is felt as impending doom.

Doubt is John Shade's spiritual bane. Despite his sensitivity and propensity to mystical experience from childhood, Shade doubts and fears experiences that are, for him, actually ecstatic. The dissolution of ego and expansion of consciousness are outside

\footnotetext{
${ }^{39}$ Petrie, Eric S. Moonrise Over the Moor: Hazel's Death in Nabokov's Pale Fire', NOJ, no.7, 2013. Roth, Mathew. 'A Small Mad Hope: Pale Fire, Hazel Shade, and the Oedipal Disaster', Nabokov's Women: The Silent Sisterhood of Textual Nomads, E. Elena Rakhhimova-Sommers, Lexington Books, 2017.
} 
'normal' experience, and fat and lame young John, envying other boys, wants to be 'normal.' No one understands or can explain his unusual 'fits.' The doctors tell him 'growing pains' or 'heart attack,' and so he doubts his personal sense of 'quiddity.' The hallmark of a mystical experience is precisely 'quiddity'-a 'suchness' and ineffable knowing. He calls his mystic fountain image 'Old Faithful,' yet he needs someone to affirm his unique experience. He rushes to the woman who had the (misprinted) similar epiphany, but is crushed by her 'mountain' apparently not substantiating his 'fountain.' Likewise, when he excitedly feels confident in having found the answer to his metaphysical quest in 'the contrapuntal theme' $(\mathrm{P} 808,50)$ and tries to tell Sybil. Upon her wifely bromidic 'Yes, dear?' his faith (ironically, equivocally and contrapuntally) deflates into 'faint hope. ${ }^{40}$ 'Contrapuntal' denotes duality; ups will be followed by downs; doubt will counter certainty.

I have suggested that John Shade represents the higher consciousness of the tripart man, the senex. That is not actually entirely true; John Shade evinces the higher ideals of art, inspiration, intellect, compassion, etc., and in that sense the notion of the higher consciousness man holds; but John Shade's self-doubt keeps him in the loop of duality. There is a darker side to Shade. Nabokov has rather successfully convinced readers that John Shade is a kind and homey 'fireside poet,' a loving father and a faithful spouse. Kinbote however, despite his avowed esteem, lets slip the truth of his idol. He tells us that Shade's whole being constituted a 'mask' and a 'disguise' (F, 19). The Jungian persona, or mask, is the false face shown to the public. The persona is always insecure, the mask held up by a shaky hand.

\footnotetext{
40 'Faint hope' is a bi-lingual anagrammed pun: Russian 'Nadezheda (hope) is a near (faint) anagram of Hazel Shade. When Shade feels crushed it brings out the inadequate feelings of his suppressed negative anima.
} 
The persona is a complicated system of relations between individual consciousness and society, fittingly enough a kind of mask, designed on the one hand to make a definite impression upon others, and, on the other, to conceal the true nature of the individual. ${ }^{41}$

Just as the persona is created to convince others of an idealized self, Nabokov's creation of John Shade is a purposeful feint that has convinced readers of the poet's high side virtues. It is a false scent, a delusive opening move 'astutely and lovingly prepared to lead the would-be solver astray' (SM, 290). I have likewise led on the reader of this paper; it was necessary first to establish Shade as he is purposefully inaccurately depicted (a wise old man) on the thetic level of plot to illustrate Nabokov's antithetic game plan of deception through narrative entrapment; Kindly, wise John Shade has a dark dual nature.

Yet, Nabokov has cleverly left abundant clues in thetic plain sight. As W.W. Rowe has pointed out, Nabokov had a fondness for 'hiding the solution to a mystery within its presentation. ${ }^{42}$ Kinbote's extolment of his idol Shade secrets within it the opposite. John Shade's homely looks are actually the 'fashion of modern day bards' (F, 19) -in other words, a bit of a pose. Like a reverse Dorian Grey portrait, Kinbote asserts that this merely belies Shade's 'intrinsic self by the same forces of perfection, which purified and chiseled his verse.' Kinbote's appraisal is not necessarily wrong and only the opposite true. In the Jungian point of view, the unconscious is not just the source of the dark and denied aspects, but also the very source of man's higher nature. John Shade is not a complete monster. He has access to aspects of his higher nature (poetry, compassion, insight, etc.); he is just not all he seems. Although we've seen that John Shade is the false self, the persona, the senex's idealized transcendent values that he represents for Botkin are real. It is just that Botkin has separated out the light from the

\footnotetext{
41 Jung, $C W 7,305$.

${ }^{42}$ Rowe, William W., 'The Honesty of Nabokovian Deception', A Book of Things About Nabokov, C. R. Proffer, ed., Ardis, Inc. 1974.
} 
darker and egoistic parts of his nature to create the mask. Botkin has access to the higher realm of Truth and Beauty as represented in the idealized Shade. The desire for and pull of self-knowledge is a transcendent value, so Shade-as-senex represents the authentic aspect that purposefully seeks for answers, but which has been co-opted by the persona. Ultimately he finds meaning not in confirmation or conformation of an image, but in his individual creation of truth and beauty, his Art.

'Shade' is, in fact, both light and dark; his mother's maiden name, 'Lukin' comes not only from 'Luke,' as Kinbote tells us, but from ' $l u x$. . ${ }^{43}$ Kinbote hints at this oppositional quality by declaring that Shade 'was his own cancellation' (F, 19). In a Jungian sense, though, Shade-as-persona IS a monster - his looks are likened to Medusa. Just as monsters must be slain to obtain the treasure, the false and unconscious archetypes in the psyche have to be faced and conquered to obtain individuation - the treasure of the true self. The Medusa could only be slain by seeing her image in a mirror. John Shade is slain when he comes face-to-face with his mirror opposite, Gradus: 'He, too, is to meet, in his urgent and blind flight, a reflection that will shatter him.' $(\mathrm{C}, 105)$

Whoever looks into the mirror of the water will see first of all his own face. Whoever goes to himself risks a confrontation with himself. The mirror does not flatter, it faithfully shows whatever looks into it; namely, the face we never show to the world because we cover it with the persona, the mask of the actor. But the mirror lies behind the mask and shows the true face. ${ }^{44}$

The self-image (persona) is shattered upon looking into the mirror of the unconscious and seeing the rejected, denied self (shadow). Jung asserted that the persona is usually the first and easiest archetype to encounter, then the shadow. After those two, the most difficult and essential archetype to face, according to Jung, is the anima (archetype of the feminine). Following Jung's outline, first Shade (as persona) dies and

\footnotetext{
${ }^{43} \mathrm{https}$ ///forebears.io/surnames/luke\#meaning

${ }^{44}$ Jung, $\underline{C W 9 i}$, p.43.
} 
then Gradus (as shadow). Sybil (as anima) remains at large (we will seek her out later in a forthcoming paper ${ }^{45}$ ).

As archetypal allegory, Shade represents the ego's idealized self (persona), the person Kinbote would be if only he could. Kinbote relates in the foreword, 'I experienced a grand sense of wonder whenever I looked at him, especially in the presence of other people, inferior people. ${ }^{46}$ This is reminiscent of the dissociated Smurov in Nabokov's The Eye admiring his projected idealized self. Typical of an insecure inflated ego, he needs to imagine his superiority. The ego sees the persona as a cover, a protection. This is why Kinbote, as ego idolizes Shade and desires to appropriate his talent through making the poem his 'story.' He does this literally with the poem's stack of cards as protective covering, sewn into his own coat:

'Thus with cautious steps, among deceived enemies, I circulated, plated with poetry, armored with rhymes, stout with another man's song, stiff with cardboard, bullet-proof at last.' (F, 20)

Like an over-armored ego he is protected, but stiff.

Shade hints at his darker side in the apparently light-hearted bath-and-shave sequence in Canto Four. He calls himself a 'bimanist,' indicating that he operates from two sides, one sinister. There is some sinister connotation in the line, '[S]omeday I must set free/The Newport Frill in me.' (P, 54) The Newport Frill was an old style of beard with fluffy sideburns. As pointed out by Roth and DeRewal ${ }^{47}$ this may suggest a werewolf; it was once believed that a werewolf's fur was turned inside out in his human

\footnotetext{
${ }^{45}$ Sybil: Black Widow Spider at the Center of Pale Fire's Web of Sense, unpublished

${ }^{47}$ Roth, Mathew \& DeRewal, Tiffany. John Shade's Duplicate Selves, NOJ, Vol.III 2009. The authors cite this as evidence of Shade's dissociated "double" personality, which is not quite the same as I maintain. They postulate Shade as the main character who creates Kinbote as a dissociated personality, projected as Shade's neighbor, Prof. Botkin. I believe it is unnecessary to try to make these cumbersome relationships work on the 'thetic' plot level. I maintain that Shade, as archetypal persona of Prof. Botkin's psyche on the antithetic level, is a more precise and elegant solution.
} 
form. The word 'versipel,' a term Shade uses for ' $[\ldots]$ that odd muse of mine' $(\mathrm{P}, 55)$

may be a poetical pun on 'versifier,' but it is, in fact, a truncated form of the Latin word versipellis (turn-skin), a taxonomic word also frequently used to denote 'werewolf.' Jung uses the alchemic term for Mercurius:

Mercurius, following the tradition of Hermes, is many-sided, changeable, and deceitful. Dorn speaks of 'that inconstant Mercurius' and another calls him versipellis (changing his skin, shifty). He is duplex and his main characteristic is duplicity. It is said of him that he 'runs round the earth and enjoys equally the company of the good and the wicked' He is 'two dragons' the 'twin', made of 'two natures or 'two substances." 48

The 'two dragons' are the low and the high side of the unconscious, the Devil and the Divine. Jung states that Mercurius, the shape-shifter, stands for all the archetypes of the unconscious. He claimed all the archetypes were shadows, as well, since unconscious. Therefore, Shade, as his name implies, as persona is also a shadow, just as all the characters in Pale Fire are archetypes of the unconscious.

Shade's odd inner muse seems rather sinister; the poetic sublimation of his dark side, 'that patch of prickliness,' is always itching to be expressed. There is a possibility of homosexual fear in the slang word of 'left hand' (Kinbote is left-handed and Nabokov's early drafts of Pale Fire suggested that Shade was homosexual, or at least threatened by homophobia). No wonder he writes, 'Now I shall speak of evil and despair'! (P, 54) These words do not seem so facetious now.

Shade appears to be tortured by his dark side. He drinks. He has been seeking liberation, he mentions, ' $[\ldots]$ all my twisted life' (P, 180). John Shade is living in the house he was born in, has had the same job and the same wife for forty years! His outer life appears to have been arrow straight. Nabokov slyly presents John Shade as such a homey, happily married character, that not only has his selfish concern over his daughter

${ }^{48}$ Jung, $C W 13$, p. 217. 
not received much notice, his 'twisted life' and his betrayal of his marriage have received slight attention.

Kinbote relates several instances that suggest Shade was having an affair with an attractive young co-ed:

Far from me be it to hint at the existence of some other woman in my friend's life. Serenely he played the part of exemplary husband assigned to him by his small-town admirers and was, besides, mortally afraid of his wife. (C, 175)

Kinbote's dissemblance is another apt example of Rowe's 'honesty of Nabokovian deception.' He denies the rumors but takes the opportunity to spread them when he invites to a dinner with John and Sybil '[...] that girl in the black leotard,' the same '[...] stunning blond' that Professor Hurley teases Shade about $(\mathrm{C}, 177)$. The girl arrives late, apparently causing John and Sybil to leave uncomfortably post-haste.

Kinbote's craziness is another artful feint Nabokov has used to distract us; we learn early to assume that Kinbote is an 'unreliable narrator' and then ignore him, or moreover expect the opposite of his statements to be true. Nabokov has created it so that readers think they see through Kinbote and therefore dismiss him. If we instead assume this infidelity of Shade's to be the case, then we know that Shade may have a thing for young girls. This suggests a link of the novel with Lolita. As Alfred Appel Jr. points out, 'shade' is 'umber,' the French pronunciation of 'Humbert.' This interpretation would throw a bit of shadow onto John and Sybil's 'happy' marriage. ${ }^{49}$

Further, one of Shade's discarded drafts suggests again homosexual fear:

I like my name: Shade, Ombre, almost a 'man'

In Spanish...

\footnotetext{
${ }^{49}$ I address the Shade marriage in a forthcoming paper, 'Sybil: Spider at the Center of the Web of Sense' (MR3) and Jungian anima issues in Pale Fire in my (MR 'Vanessa Atalanta: Butterfly of Doom.' (MR1)
} 
Ombrioles, Lavender's shadowy pornography found at Villa Libitina was mostly homosexual, as the photographer's name might imply. Perhaps this quote was actually a discard from Nabokov's original plan for Shade's homophobia. He may have decided to keep it as a subtly hidden suggestion of Shade's shadowy side.

\section{The Ego: Kinbote:}

The ego is the conscious identity between the lower and higher unconscious archetypes. This positioning makes one of the variants of the suggestively near anagrammatic word 'bodkin' meaningful: 'a person wedged in between two others. ${ }^{50}$ This also suggests that Kinbote, as small self (ego) is derivative from Botkin as whole self, just as the ego archetype is derivative from the self archetype.

Jung claimed that the ego itself was also an archetype, in that it was made up of accrued unconscious complexes, thus did not have the ontology of the true self which is comprised of all three parts of the psyche - conscious, unconscious and superconscious. The ego according to Jung is derivative of the self-archetype, but only as the conscious part, which most people take for the whole. The self archetype he saw as an innate template that forms images (symbols of wholeness) of the actual ontologic self, but the self itself is always, in the end, ineffable, unknowable by the mind. The goal, as noted, of individuation is to bring consciousness to the unconscious contents of the psyche, to become more aware of the whole self. The ego as conscious discriminating function is thus necessary; problems arise when the ego becomes inflated and dominated by unconscious material.

\footnotetext{
${ }^{50}$ Boyd, p.286, 3n.
} 
What we now think of as 'ego' was once commonly called 'pride.' Jung held that a healthy ego and a healthy sense of pride are necessary for psychological functioning; the 'deadly' sin of pride is the inflated ego. Just as Nabokov inserted the Jungian words 'shadow' and 'mask' in the text for Gradus and Kinbote, he uses the word 'pride' in connection with Kinbote. He acknowledges the bygone ego/pride equivalence when he has Kinbote insinuate modesty in his self-proclaimed 'pride,' thereby attempting to reverse the 'deadly' meaning to the 'healthy,' while ironically revealing and reversing the reverse: 'My usual shortcoming, pride, prevented me from pressing him with direct questions, but I kept reverting to my own earlier themes [...]' (C, 131). Kinbote again turns his 'shortcoming' into an asset when he realizes he has been excluded from Shade's birthday party: 'False pride prevented me from doing what I should have done - taken my royal gift under my arm and serenely marched over to that inhospitable house.' (C, 124) Referring to Gradus, Kinbote proudly proclaims his sense of pride: 'Nothing is sacred to you, neither cancer, nor exile, nor the pride of a king [...]' $(\mathrm{C}, 139)$

Sounding more like Nabokov himself, Kinbote has a rare moment of selfawareness, as he discusses theology with Shade:

With no Providence the soul must rely on the dust of its husk, on the experience gathered in the course of corporeal confinement, and cling childishly to small-town principles, local bylaws and a personality consisting mainly of the shadows of its own prison bars. Such an idea is not to be entertained one instant by the religious mind. How much more intelligent it is - even from a proud infidel's point of view! - to accept God's Presence - a faint phosphorescence at first, a pale light in the dimness of bodily life, and a dazzling radiance after it? $(\mathrm{C}, 174)$

Here is the very core of Pale Fire - the psychological predicament of the ego-personality (the proud infidel) trapped by its own shadows of the unconscious. Nabokov used this same prison bar imagery in Lolita, Invitation to a beheading and Bend Sinister. The 'pale 
light' of bodily life suggests 'pale fire' as the 'divine spark' of alchemy, what Jung would call the true self.

Kinbote is a large man, a large ego. Narcissistic, self-serving, he is the epitome of what Jung terms 'ego inflation.' Here are some edifying quotes from Jung:

An inflated consciousness is always egocentric, and conscious of nothing but its own existence. It is incapable of learning from the past, incapable of understanding contemporary events, and incapable of drawing right conclusions about the future. It is hypnotized by itself and therefore cannot be argued with. It inevitably dooms itself to calamities that must strike it dead. Paradoxically enough, inflation is a regression of consciousness into unconsciousness. This always happens when consciousness takes too many unconscious contents upon itself and loses the faculty of discrimination, the sine qua non of all consciousness. ${ }^{51}$

It is often tragic to see how blatantly a man bungles his own life and the lives of others yet remains totally incapable of seeing how much the whole tragedy originates in himself and how he continually feeds it and keeps it going. Not consciously, of course- for consciously he is engaged in bewailing and cursing a faithless world that recedes further and further into the distance. Rather, it is an unconscious factor that spins the illusions that veil his world. And what is being spun is a cocoon, which in the end will completely envelop him. ${ }^{52}$

Everyone who has dealings with such cases knows how perilous an inflation can be. No more than a flight of steps or a smooth floor is needed to precipitate a fatal fall..$^{53}$

I've quoted quite a bit here from Jung to emphasize how thoroughly Kinbote fits Jung's description of an inflated ego headed for a fall. Kinbote's collapse is foreseen in the novel's title, Pale Fire, taken from Timon of Athens, Shakespeare's tale of a parasitic, bombastic, solipsistic fool who, alone and bitter, retreats into a cave. Timon ends up repudiating the poet and the alchemist he once courted - just as psychologically Kinbote (as ego) must dis-identify with his idealized self (Shade/persona/poet) and lower self (Gradus/shadow/Mercurius) to individuate. (Allegorically and archetypally, he also needs to confront and assimilate his anima - which I address in a forthcoming paper. ${ }^{54}$ ) Psychologically, the ego, after confronting and subsuming these unconscious archetypes, then voluntarily surrenders its presumed autonomy to the greater self - a process often

${ }^{51}$ Jung, $C W 12,48$.

${ }^{52}$ Jung, $C W 12,294$.

${ }^{53}$ Jung, $C W 12,308$.

${ }^{54}$ Sybil: Black Widow Spider at PALE FIRE's Web of Sense, unpublished. (MR 
referred to as 'ego-death.' Symbolically, this may look like suicide. The fear of ego-death keeps the archetypes unconscious and threateningly autonomous. Kinbote hints at this when he writes, 'at times I thought that only by self-destructions could I hope to cheat the relentlessly advancing assassins who were in me [...]' $(\mathrm{C}, 75)$. This is also clearly an indication of Kinbote/Botkin's mind as the real locale of action and plot and characters in Pale Fire.

Although it seems to be John Shade who is in an eschatological crisis, on a journey of individuation, it should not be surprising, from the archetypal allegorical aspect, that Kinbote, too, is on his own transcendental 'journey.' Kinbote's travels and travails from Zembla to Arcady are a parody of the well-worn mythologicalpsychological path, popularized by Joseph Campbell's Jungian inspired book The Hero With a Thousand Faces (1949). The 'hero' is a sort of everyman, hence we might suspect that Nabokov chose the name 'Charles' for its etymologic root, meaning simply 'man., 55 In typical Nabokovian contrapuntal style, the name is also associated with the Russian word for 'king' - karol-derived from 'Charlemagne. ${ }^{56}$ What better name for an inflated ego that imagines itself a great king!

In the typical 'Hero's Journey, ${ }^{57}$ (a.k.a. 'universal monomyth') an ordinary seeming innocent, who unbeknownst is actually of royal or semi-divine birth, is forced to leave his comfortable life and home. He undergoes various trials, climbing mountains, crossing seas, and descending to the underworld. Along the way a monster that guards a treasure must be slain. Eventually he obtains the precious boon or treasure and returns

\footnotetext{
${ }^{55}$ Roth, Mathew. A Source of Character Names in PALE FIRE, The Nabokovian 59 (2007):5-9. Roth, citing Nabokov's favored book on the subject, Baring-Gould states "Carl signified a man generally" ${ }^{56}$ Johnson, cites: Maks Fasmer, Etimologigicheskii slovar' russkogo iazyka, vol. 2 (Moscow, 1967)

${ }^{57}$ I deal with this subject more extensively in my paper, 'Kinbote's Hero's Journey,' unpublished. (MR6)
} 
home as the true hero he was destined to be. In Kinbote's case, the boon is the precious manuscript. Unfortunately, the 'monster' slain is John Shade.

Kinbote does not recognize that his projected persona idolization of Shade is an impediment to attaining his true 'treasure' (individuation). He sees Shade as a god-like ideal. In his desperate need to be close to Shade, Kinbote clearly conflates him with God:

I always feel in my bones that there is a chance yet of my not being excluded from Heaven, and that salvation may be granted to me despite the frozen mud and horror in my heart. As I was ascending with bowed head the gravel path to my poor rented house, I heard with absolute distinction, as if he were standing at my shoulder and speaking loudly, as to a slightly deaf man, Shade's voice say: 'Come tonight, Charlie.' (C, 197)

Joseph Campbell states that for the hero to attain his goal he must slay ' $[\ldots]$ that self-generated double monster-the dragon thought to be God (superego) and the dragon thought to be Sin (repressed id). ${ }^{58}$ (Campbell is here using Freudian terminologyroughly equivalent to Jung's persona and shadow.) By the completion of Kinbote's 'journey,' both John Shade (idealized higher consciousness) and Gradus/Jack Grey (repressed unconscious) are slain.

Gradus assassinates Shade, just like the confrontation with the shadow annihilates the idealized persona. As Shade lies dying, Kinbote says, 'I felt - I still feel - John's hand fumbling at mine... as if passing to me, in a sublime relay race, that baton of life.' This indicates the integration of the persona into ego-consciousness. When Gradus dies, Kinbote says, 'He died, not so much because having played his part in the story he saw no point in existing any longer, but because he could not live down this last crowning botch - killing the wrong person when the right one stood before him. In other words, his life ended not in a feeble splutter of clockwork but in a gesture of humanoid despair.' (C, 228) Psychologically, the shadow behaves mechanically, and plays its part without

\footnotetext{
${ }^{58}$ Campbell, p. 120.
} 
consciousness; but seeing its error there is no longer a reason to exist. It seems, however, that Kinbote at this point has not fully absorbed the import of these events.

All of the major archetypal characters converge at the scene of John Shade's demise. (I discuss these others more fully in separate papers.) Besides the ego, shadow and persona, there is Gerald Emerald, (as trickster nemesis) ${ }^{59}$ who drives Gradus to the fatal site. Three versions of the anima show up, emblematic of what Jung described as the three phases of the Moon goddess - Maiden, Mother, and Crone. Hazel (innocent, rejected soul) appears as the transmogrified spirit of the doom-heralding Vanessa atalanta butterfly; Sybil (antagonistic Mother anima) ${ }^{60}$ shows up with her club-mate, Dr. Sutton's daughter, Mrs. Starr (wisdom anima). Jung claimed that when the antagonistic anima is overcome she in turn becomes an ally and guide to the soul. This wisdom aspect of the anima usually appears in the company of an aged spiritual teacher, an archetype that Jung called the "Wise Old Man." Kindly, wise old Dr. Sutton has these attributes and is present by luminous proxy in his Sun reflecting window panes. The Gnostics and alchemists called the essential soul to be realized "the star in man." With Mrs. Starr's arrival, it would seem the scene is set for a transformative Jungian individuation. The gardener, Balthasar (self archetype), ${ }^{61}$ is on hand to disarm Gradus (light trumping dark with a spade). The self archetype is associated with the Gnostic demiurge. Kinbote even calls him "our savior."

\footnotetext{
${ }^{59}$ Ross, Mary (MR1)

${ }^{60}$ Ross, Mary (MR3)

${ }^{61}$ Ross, Mary (MR4)
} 
However, despite having gone through a classic 'Hero's Journey, ${ }^{62}$ Kinbote has continually resisted any transformation or transcendence. Even after the deaths of his persona and shadow, he remains desperately on the run, believing in the protection of his appropriation of Shade's talent. Above all, he fails to come to terms with the anima, the crucial archetype essential to the Jungian model of individuation. Jung writes about the alchemists vacillating between triunity and the quaternity. The alchemists' redeemed wisdom anima, as "Sapientia" or "Sophia," is the fourth component necessary for spiritual transmutation. This is implied in the Hermetic axiom of the legendary Maria Prophetissa, "One becomes two, two becomes three, and out of the third comes the one as the fourth." Thus the fourth, the feminine, signals completion into a whole - the self, the One.

Kinbote's failure to deal with his anima would suggest an incomplete transformation. In his final rant, Kinbote's projected future lives promise nothing more than more of the same in different costume. John Shade on his parallel journey reaches an apotheosis, a sense of surety, but is then shot down. Even Gradus fails his mission and kills himself. Transcendence would seem to be a transient and unreliable reality and perhaps even a bogus goal. This could be summed up in the line Kinbote gives to Hazel in his imagined haunted barn scenario, 'Life is hopeless, afterlife heartless' $(\mathrm{C}, 148)$. The game is a stalemate, the path a dead end.

Or, we might consider that despite his unremitting recalcitrance through the journey, we don't really know the fate of Kinbote after he suicides. He was still fully, desperately ego-driven in his final rant, but seemingly undergoing a transformation of character; perhaps we can imagine that he actually did surrender, transform and transcend

${ }^{62}$ Ross, Mary (MR6) 
once he killed himself. Assuming that Kinbote does effect a successful transcendence, then he (i.e. Botkin) has effected the goal of the whole process: ego death. It is that rare chess solution - a solus rex "sui-mate." He wins through losing. The king is dead; long live the King.

It is also possible that Nabokov may be parodically suggesting that Jung is wrong about the importance of the anima and that one can transcend without subsuming the inner feminine. I explore this more fully in "Sybil: Spider at the Center of PALE FIRE's Web of Sense" (MR3). A conclusive interpretation remains a typical Nabokovian 'permanent mystery. ${ }^{63}$

\section{CONCLUSION:}

The notion of the tri-part man appears to be universal to cultures throughout the world. In this vein, Carl Jung's theories of archetypes and alchemy offer a consistent rationale for the parodic and allegorical relationship of the three main characters of Pale Fire: Gradus, Shade and Kinbote as three aspects of the same individual, V. Botkin. In addition to Jung's archetype theories as major substrate, Jung's theories of alchemy as psychological process (individuation) further link to the pervasive allusions in Pale Fire to alchemy, which in turn links to other thematic occult elements. Alchemy and its allied occult arts of astrology and numerology suggests links to the many artists mentioned or alluded to in Pale Fire who were involved with the occult, which in turn links to questions of death and the afterlife - Shade's quest for transcendence. Kinbote's Jungian 'Hero's Journey' is likewise a transcendent path, reflected and supported in Pale Fire's

${ }^{63}$ Rutlege, David S., Nabokov's Permanent Mystery, Jefferson, NC: MacFarland \& Co., Inc., 2011. 
allusions to the world epics and mythologies. Gradus, as emblematic of the Shadow revolution in consciousness, is on his own path of emergent realization. We are told in the text that Gradus' journey is synchronized with Shade's poem, but now we can see that Kinbote is likewise on a parallel journey of coming to consciousness. All three characters are on parallel paths towards unification which Jung termed individuation. The common thread is the quest for transcendence - of self, of death and of Art-that appears to run through the warp and weft of Jung's archetypes and alchemy. These three themes of transcendence, (self, death, and Art) in fact, correlate to the converging aims of the Tripart Man. Kinbote is on a journey (albeit recalcitrant) of transcending ego-self; it is egodeath that effects spiritual transcendence and Gradus is the instrument; John Shade, as the idealized aspect of Botkin, is supremely blest. He is an artist; he has an epiphany of meaning and completes his poem, a transcendent work of art.

Evincing the three universal aspects of man - lower, ego and higher (Jungian shadow, ego, persona) - it becomes evident that together they must represent one man, and that one man can be no other than Professor V. Botkin, as representative of the whole self. Once we can see the three main characters as the tri-partite aspects of Botkin the antithetic level of allegory and the synthetic theme of transcendence begins to take shape. Whether Botkin succeeds in transcendence of ego, death, and art, Nabokov leaves typically ambiguous in the end.

Mary Ross 


\section{WORKS CITED}

\section{BOOKS:}

Nabokov, Vladimir, Pale Fire, New York: Everyman's Library, Vintage International, 1992. $($ Poem $=$ PF, Commentary $=C, F=$ Foreword, $I=$ Index $)$

--- Speak Memory. New York: Vintage International, 1989. (SM)

---Strong Opinions. New York: Vintage International, 1989. (SO)

---The Annotated Lolita. A. Appel, Jr., Ed. New York: Random House Vintage Books, 1991. (AL)

---Lectures on Literature. F. Bowers, Ed., New York: Harcourt, Inc., 1980. (LOL)

---Nabokov: Novels 1955-1962. Penguin Putnam, Inc., 1996. (N1)

--- Nabokov: Novels 1969-1974. Ada, Penguin Putnam, 1996. (N2)

Jung, Carl Gustav. Collected Works Princeton: Princeton/Bollingen, 1969. (CW, [xx])

--- Modern Man in Search of a Soul. "Psychology and Literature," Oxton: Routledge Classics 2001. (MMSS)

--- Psychology and the Occult, The Psychological Foundation of the Belief in Spirits. Princeton: Routledge Classics, Princeton University Press, 2008. (Jung, P\&O)

--- Memories, Dreams, Reflections. New York: Vintage Books, Random House, 1963. (Jung, MDR)

---C.G. Jung: Letters. Vol. 2: 1951-1961, Trans. R.F.C. Hull, Princeton: Princeton University Press, 1975. Bollingen Series XCV: 2, (Jung, Letters) 
Bodkin, Maud. Archetypal Patterns in Poetry: Psychological Studies of Imagination. London: Oxford University Press, 1937. (MB)

Boyd, Brian. Nabokov's Pale Fire : The Magic of Artistic Discovery. Princeton: Princeton UP, 1999.

Campbell, Joseph. The Hero with a Thousand Faces. Princeton: Princeton/Bollingen Commemorative Edition, 2004.

Frye, Northrop. Anatomy of Criticism. Princeton: Princeton University Press, 1957.

Meier, Michael. Atalanta Fugiens: Emblemata Nova de Secretis Naturae Chymica, 1618, Old Book Publishing Ltd., 2015.

Rutledge, David S. Nabokov's Permanent Mystery, Jefferson, NC: MacFarland \& Co. Inc, 2010.

Shakespeare, Wm. Timon of Athens

Wood, Michael. The Magician's Doubts: Nabokov and the, Risks of Fiction. Princeton: Princeton University Press, 1994.

\section{PAPERS:}

Abraham, Lyndy. 'Nabokov's Alchemical Pale Fire'. DQR, 20(2), pp.102-119.

Hamrit, Jacqueline. ‘Authorship in Nabokov's Prefaces', NOJ, Vol. IX (2015).

Johnson, D. Barton. 'Vladimir Nabokov's Solus Rex and the 'Ultima Thule"

Theme.' Slavic Review 40, no. 4 (1981): 543-56. doi:10.2307/2496262.

McCarthy, Mary. 'Bolt from the Blue', The New Republic, June 3, 1962.

Petrie, Eric S. 'Moonrise Over the Moor: Hazel's Death in Nabokov's Pale Fire', NOJ, Vol. VII, 2013.

Roth, Mathew. 'A Small Mad Hope: Pale Fire, Hazel Shade, and the Oedipal Disaster', Nabokov's Women: The Silent Sisterhood of Textual Nomads, Ed. Elena RakhhimovaSommers, Lanham, MD: Lexington Books, 2017.

---Roth, Mathew. 'A Source of Character Names in Pale Fire', The Nabokovian 59 (2007):5-9 
Roth, Mathew \& DeRewal, Tiffany.' John Shade's Duplicate Selves', NOJ, Vol.III 2009.

Rowe, W.W. 'The Honesty of Nabokovian Deception', A Book of Things About Vladimir Nabokov, Carl R. Proffer, Ed., Ann Arbor, 1974, pp.176-178

Knapp, Shoshana. 'Hazel Ablaze: Literary License in Nabokov's Pale Fire.' Essays in Literature (Macaomb, IL), Spring 1987.

Ross, Mary. 'Vanessa Atalanta: Butterfly of Doom', The Nabokovian Notes 75, Spring 2018. https://thenabokovian.org/notes-commentaries/ross-sp2018 (MR 1)

--- Kinbote's Hero's Journey: Transcendent Path or Dead End?' (Unpublished) https://independent.academia.edu/MaryRoss22 (MR 2)

--- 'Sybil: Spider at PALE FIRE's Center of the Web of Sense', (Unpublished). https://independent.academia.edu/MaryRoss22 (MR 3)

---'Balthasar, Prince of Loam: PALE FIRE's Dark Savior,' (Unpublished). https://independent.academia.edu/MaryRoss22 (MR 4)

---'The Man in Green and the Man in Brown: The Trickster and Shadow Archetypes in Nabokov's Pale Fire," The Nabokovian Notes 75, Spring 2018. https://thenabokovian.org/node/35665 (MR 5)

---'Kinbote's Hero's Journey,' (Unpublished) https://independent.academia.edu/MaryRoss22 (MR 6) 